\title{
The Specificity of the Formation of the Duchies of Courland and Semigallia in the Confessional Era
}

\author{
D. I. Weber
}

For citation: Weber D. I. The Specificity of the Formation of the Duchies of Courland and Semigallia in the Confessional Era. Vestnik of Saint Petersburg University. History, 2018, vol. 63, issue 1, pp. 136-147. https://doi.org/10.21638/11701/spbu02.2018.109

The article examines the specific character of the process of secularization of the Order's possessions in the Baltic region. It explores the formation of the Duchy of Courland and Semigallia as a result of secularization of possessions of the Livonian branch of the Teutonic Order. The first half of the $16^{\text {th }}$ century had brought about political and religious changes of great importance to the Baltic States, which had been associated with the spread of Protestantism in the region. Protestant duchies were formed out of the possessions of the Catholic religious-military corporation. The article focuses on religious questions in general and King Sigismund's guarantees to the classes professing Lutheranism, in particular. First implemented in 1525 by the Prussian Grand Master, Albrecht von Brandenburg-Ansbach, secularization was then carried out in 1561 in Livonia by landmaster Gotthard von Kettler. The process had resulted in the disappearance of Ordensstaat as a political entity and changes in the political map of the region. The article also analyses the meeting of the Order's gebietigers on April 5, 1560, reflecting the mood within the religious-military corporation before secularization, which was connected with the military and political situation caused by the Livonian war, and religious issues. The given examples signified the beginning of the age of Confessionalization as early as the mid-twenties of the XVI century, i.e. somewhat earlier than it had been asserted in historiography).

Keywords: Teutonic order, Reformation, Baltic region, secularization, Duchy of Courland and Semigallia, Gotthard Keller.

Weber Dmitriy I. - PhD in History, Assistant, St. Petersburg State University, 7-9, Universitetskaya nab., St. Petersburg, 199034, Russian Federation; d.veber@spbu.ru

Вебер Дмитрий Иванович - канд. ист. наук, ассистент, Санкт-Петербургский государственный университет, Российская Федерация, 199034, Санкт-Петербург, Университетская наб., 7-9; d.veber@spbu.ru

This article was prepared for the project of Russian Foundation for Humanities 16-01-00108 "Institutes, theory and practice of Western European monarchies in the XVII-XVIII centuries".

(c) Санкт-Петербургский государственный университет, 2018 


\section{Специфика образования герцогства Курляндского и Семигальского в конфессиональую эпоху}

\section{Д. И. Вебер}

Для цитирования: Weber D.I. The Specificity of the Formation of the Duchies of Courland and Semigallia in the Confessional Era // Вестник Санкт-Петербургского университета. История. 2018. Т. 63. Вып. 1. С. 136-147. https://doi.org/10.21638/11701/spbu02.2018.109

В статье рассматривается феномен изменения конфессиональных границ Польши и Великого Княжества Литовского протестантскими герцогствами. Основное внимание уделено формированию герцогства Курляндского и Семигальского в результате секуляризации владений Ливонского отделения Немецкого ордена. В статье анализируется специфика этих процессов. Первая половина XVI в. отмечена важными не только политическими, но и конфессиональными изменениями на территории Прибалтики, что связано с распространением протестантизма в регионе. Формирование конфессиональных границ произошло в результате появления протестантских герцогств, выделившихся из владений католической духовно-рыцарской корпорации. В рамках статьи акцент смещен на конфессиональный вопрос, в частности, на гарантии, выданные королем Сигизмундом сословиям, исповедовавшим лютеранство. Сначала секуляризация была проведена в 1525 г. Великим магистром Альбрехтом Бранденбург-Ансбахским в Пруссии, а в 1561 г. - ландмайстером Готтхардом Кеттлером в Ливонии. Результатом этих процессов стали исчезновение Ordensstaat как политического образования и изменение политической карты региона. Рассматривается, в том числе, собрание гебитигеров Ордена 5 апреля 1560 г., отражающее настроения внутри духовно-рыцарской корпорации накануне секуляризации, связанные как с военно-политической обстановкой, вызванной Ливонской войной, так и с религиозным вопросом.

Ключевые слова: Немецкий орден, герцогство Курляндское и Семигальское, Готтхард Кеттлер.

The sixteenth century had brought about significant changes in the social, religious and political landscape of Europe, thereby marking the transition from the late Medieval to Early Modern Times. In these conditions, especiallyagainst the background of the spread of Reformation, old social institutions and medieval corporations underwent a drastic change. One of the best examples demonstrating the specific character of these processes is that of the Baltic region. Here, Prussia and Livonia appear to be of particular interest since a large portion of these lands used to belong to the Teutonic Order that had owned lands there since the Crusade era up to the height of the Middle Ages. Events of 1525 and 1561/2 years had changed not only the borders but also the political status of the territory, marking the end of an era. The old state of the Order ('Ordenstaat') had ceased to exist, having thereby strengthened the position of Poland.

The secularization movement of the sixteenth century is inseparable from the transformations brought about by the Reformation, which are often considered to be the boundary between the Middle Ages and Early Modern Times ${ }^{1}$. The liquidation of the Order in the Baltic region had ended the period of possessions that used to form the basis of the military order, which presented, according to the words by Henryk Lowmiański,

${ }^{1}$ Schilling H. Reformation - Umbruch oder Gipfelpunkt eines Temps des Reformes // Die frühe Reformation in Deutschland als Umbruch. Gütersloh, 1998. S. 13-24. 
a religious model ${ }^{2}$. The transformation had led to new political formations with a new secular legal status. An integral part of this process was a shift from the Catholic to the Protestant religion, which had created confessional borders separating Poland and the Grand Duchy of Lithuania from the above-mentioned Protestant duchies.

However, an obvious question is why we emphasize the situation with the Order's lands in the Baltic States? The main reason is that the Reformation movement and secularization had led to the Order's state ("Ordensstaat") being eliminated and the political map of the region being changed completely. The transition had happened in two stages, with the secular Duchy in Prussia being formed out of the Order's possessions in 1525, and the same thing happening in Livonia in 1561. The sixteenth century Order state had to develop against the background of the same two major trends as the rest of Europe. First of all, increased spread of the Evangelical doctrines was observed, and parallel attempts at reforming the Catholic Church were taken. Secondly, new political forms of state organization, based on centralizing forces, were emerging The example of the Order history in the Baltic States is quite specific to the European Reformation movement study, in general, and that on the territory of the Holy Roman Empire, in particular, since the emergence of new denominations had indirectly contributed to the transformation of Catholic religious-military corporations into a secular Duchy. A question about the interconnection of processes in Livonia and Prussia has been explored ${ }^{3}$. However, the article puts an emphasis on the processes of secularization in the context of general reformation.

The Teutonic order's possessions in the Baltic region do not quite fit into the scheme of the development of the Reformation outlined by historiography ${ }^{4}$.

The German historiography has put forward various points of view at different times, classifying the process of Reformation according to its initiaters: initiated by the ruler, by the urban population ${ }^{5}$ and even by the peasant community ${ }^{6}$. The system became even more complicated when Eke Wolgast developed various models of the duke's Reforma-

2 Łowmiański H. Rol' rycarskih-ordenov v Pribaltike XIII-XIV vv. M., 1974. P. 69.

3 See, for example: Arnold U. Hochmeister Albrecht von Brandenburg-Ansbach und Landmeister Gotthard Kettler // The Military orders and the Reformation. Choices, state building and the weight of tradition. Utrecht, 2006. P. 11-31; Adam J. Inflanty i Księstwo Kurlandii i Semigalii - inflanckie "Prusy" trochę inaczej. Kilka uwag o zapomnianej Unii Wileńskiej 1561 roku // Miscellanea Historico-Archivistica. 2013. N 20. P. 19-43, and some researches in collected articles: Preussen und Livland im Zeichen der Reformation / Hrsg. Von A. Mentzel-Reuters, K. Neitmann. Osnabrück, 2014; Magnus H. Die Säkularisationen der geistlichen Staaten Livlands 1558-1561. Typologie und Verglech // Latvijas Zinātṇu akadēmijas vēstis. A daḷa, Sociālās un humanitārās zinātnes. 2013. N 67. S. 90-107.

${ }^{4}$ Friedeburg R.von, Schorn-Schütte L. Politik und Religion: Eigenlogik oder Verzahnung? Europa im 16 Jahrhundert // Historische Zeitschrift. 2007. N 45. S. 2; Steinmetz M. Die historische Bedeutung der Reformation und die Frage nach dem Beginn der Neuzeit in der deutschen Geschhichte // Zeitschrift für Geschichtswissenschft. 1967. N 15. S. 1171-1172; Foschepoth J. Reformation und Bauernkrieg im Geschichtsbild der DDR. Berlin, 1976; Wohlfeil R. Reformation als frühbürgerliche Revolution? Die deutsche Reformation in der Historiographie der DDR // Geschichtwissenschaft in der DDR. Vor- und Frühgeschichte bis Neuste Geschichte / Hrsg. von A. Fischer, G. Heydemann. Berlin, 1990. Bd. II. S. 177-215 and others.

5 Moeller B. Reichsstadt und Reformation: Neue Ausgabe. Berlin, 1987; Greyerz K. von. Stadt und Reformation: Stand und Aufgaben der Forschung // Archiv für Reformationgeschichte. 1985. N 76. S. 6-63.

${ }^{6}$ Ziegler W. Reformation als Gemeindereformation? // Archiv für Reformationgeschichte. 1990. N 72. S.41-452; Blickle P. Gemeindereformation. Die Menschen des 16 Jahrhunderts auf dem Weg zum Heil. München, 1987; Brady Th. Turning Swiss. Cities and Empire 1450-1550. Cambridge, 1985; Rudersdorf M. Die deutsche Reformation - nur ein "urban event"? // Europa in der Frühen Neuzeit. Köln; Weimar; Wien, 2002. 
tion $^{7}$. In recent years, the concept of confessionalization, involving the active participation of social groups in the process of reform, became widespread ${ }^{8}$. In addition, Heinz Schilling has introduced the notion of the "second reformation" ("Zweite Reformation") 9 to denote confessional changes, which required completing the transformation of a confession through a "reform of life" 10 . Some researchers of confessional era equated the concept of "the second Reformation" to the term "Reformation", which was largely depended on the will of the Prince, Duke, ruler, etc. Thus, the important role belonged to the family and dynastic influence, and not to the influence from below as in the "first Reformation" of the 1520 -ies ${ }^{11}$. The interpretation of "the second Reformation" as initiated by "the prince" was actively supported by other researchers ${ }^{12}$.

The idea of the connection between confessionalization and secularization is often subject to debate. It's sometimes maintained that growing divergence between secular authorities and the Church posed a challenge to its functional essence ${ }^{13}$.

Thus, Wolfgang Reinhard, refuting the allegation of the authorities displaying an overpragmatic approach towards the religious issue ${ }^{14}$, noted in his evaluation of the relationship between politics and religion that the actions of the German territorial rulers had not only depended upon political calculation, but also on the religious and social orientation and the socio-cultural process reflected in confessionalization. In in the case of Prussia and Livonia, in contrast to the rest of the Holy Roman Empire, in the Baltic Lands, which were formally included there, the secularizing process was initiated by the head of the Catholic religious-military corporation, who was not, however, the sole land owner as all formal decisions were made by the Chapter. In this respect, the transformation that the Order's possessions in the Baltic States had undergone, enables us to refine the current concepts of confessionalization and Reformation. First, we should pay attention to the date that marked the start of change - the year 1525. In fact, according to the confessionalization chronology proposed by Heinz Schilling, this era began with the end of the 40ies $^{15}$, and this is what the reference to the example of the Order can clarify. The problem of Reformation and secularization had presented itself to the Order in Prussia and Livonia in the mid 20-ies of the sixteenth century. The Grand Master and Landmaster as the leaders of the catholic spiritual knighthood were faced with the choice whether to secularize the possessions of the Order or to maintain the status of a religious knighthood corporation.

7 Wolgast E. Formen landesfürstlicher Reformation in Deutschland. Kursachen-Würtenberg-Kurpfalz // Die dänische Reformation vor ihrem internationalen Hintergrund. Göttingen, 1990. S. 57-90.

8 Schilling H. Aufbruch und Kriese: Deutschland 1517-1648. Berlin, 1988; Reinhard W. Probleme deutsche Geschichte 1495-1806. Reichsreform und Reformation 1495-1555. Stuttgart, 2001; Lanzinner M. Konfessionelles Zeitalter 1555-1618. Stuttgart, 2001; Reinhard W.Zwang zur Konfessionalisierung? Prolegomena zu einer Theorie des konfessionallen Zeitalters // Zeitschrift für Historische Forschung 1983. N 10. S.229.

9 Schilling H. Konfessionskonflikt und Staatsbildung: Eine Fallstudie über das Verhältnis von religiosem und sozialem Wandel in der Frühneuzeit am Beispiel der Grafschaft Lippe. Gütersloh, 1981. S. 50.

10 Schmidt H. R. Konfessionalisierung im 16. Jahrhundert. München, 1992. S. 80.

11 Ibid. S. 81.

12 Rabe H. Reich und Glaubensspalting. Deutschland 1500-1600. München, 1989. S.369; Ziegler W. Territorium und Reformation // Historisches Jahrbuch. 1990. N.110. S.73; Klueting H. Das konfessionelle Zeitalter 1525-1648. Stuttgart, 1989. S. 11-12.

${ }_{13}$ Schilling H. Konfessionskonflikt und Staatsbildung. S. 274; Wohlfeil R. Einführung in die Geschichte der deutschen Reformation. München, 1982. S.43; Schulze W. Sozialdisziplinierung in der Frühen Neuzeit // Zeitschrift für historische Forschung. 1987. N 14. S. 265-302; Reinhard Zwang zur Konfessionalisierung? S. 229.

${ }_{14}$ Schilling H. Konfessionskonflikt und Staatsbildung. S. 17.

15 Ibid. S. 275. 
Therefore, it seems possible to extend the period in question and, following the opinion of Harm Klueting, to date its start back to $1525^{16}$. However, in modern historiography there is an attempt at connecting the beginning of the confessional era with the year 1500, i.e., to coincide it with the beginning of the Early Modern Times ${ }^{17}$.

1525 was the year of the secularization of the Order's possessions in Prussia by the Grand Master Albrecht von Brandenburg (Brandenburg-Ansbach). The land was converted into a secular Duchy. The event might have been facilitated by the Thorn Peace Treaty of 1521, signed with Poland for four years. Hostilities were to resume in 1525, so the Order was searching for allies. The Grand Master was looking for ways out of the crisis. In these circumstances, Albrecht got supported by Martin Luther. It is believed that the Teutonic Order expressed a direct interest in Protestantism in $1523^{18}$. It was the year when Johann Oden was sent to Wittenberg with his credentials and the instructions of the Grand Master Albrecht von Brandenburg ${ }^{19}$. Albrecht gave Martin Luther the statutes to look through and give advice on the possible ways to reorganize the spiritual knighthood corporation ${ }^{20}$. The Wittenberg reformer replied in his address "To the gentlemen of the Teutonic Order, with a wish for them to avoid false chastity and turn to the right, honest chastity" ${ }^{21}$. He advised the brethren not only to renounce the vow of celibacy, but also to leave the Order. Martin Luther's message was written in the context of his criticism of the monasteries ${ }^{22}$. He later wrote to the theologian Johann Briesmann that he had advised converting "Prussia into a political form or a Principality or a Duchy"23. The reformer (compared the spiritual and the secular aspects of the Order. This had resulted in Albrecht von Brandenburg-Ansbach accepting Protestantism, and giving his oath to the Polish king in the market square in Krakow on April 10, $1525^{24}$.

As on many other occasions, Martin Luther spoke the language of theology and ignored the secular matters ${ }^{25}$. Despite the mediation of Philipp Melanchthon, Albrecht did not give an immediate answer. The meeting only took place on November 19, $1523^{26}$. Some Gebietigers, the highest officials of the Order, supported Albrecht's secularization of the Order in Prussia. A significant role belonged to Friedrich von Heideck, Albrecht's close ally and advisor, who could be called a Prussia Reformation supporter as early as in 1522-1523. He had campaigned for secularization among the members of the Order, the

16 Klueting H. Das konfessionelle Zeitalter, 216.

17 Die baltische Lande im Zeitalter der Reformation und Konfessionalisierung. Livland. 15001721 / Hrsg. von M. Asche, W. Buchholz, A. Schindling. Münster, 2009-2012. Bd. 1-4.

18 Kuhles J. Die Reformation in Livland - religiöse, politische und ökonomische Wirkungen. Hamburg, 2007. S. 278.

${ }^{19}$ Hubatsch W. Albrecht von Brandenburg-Ansbach: Deutschordens-Hochmeister und Herzog in Preussen 1490-1568. Heidelberg, 1960. S. 118.

20 Ibid.

21 "An den herrn Deutschen Orden das sie falsch keuscheyt meyden und zur rechten ehlichen keuscheyt greyffen". See in: Luther M. Werke Kritische Gesamtausgabe. Weimar, 1891. Bd. 12. S. 228-244.

22 Stamm H.- M. Luthers Stellung zum Ordensleben. Mainz, 1980. S. 64.

23 "...Prussiam in politicam formam, sive principatum, sive ducatum..." (Martin Luther's Briefe, Sendschreiben und Bedenken / Hrsg. von W. M. L. de Wette. Berlin. 1826. Bd. 2. S. 256).

${ }^{24}$ Dolezel S., Dolezel H. Die Staatsverträge des Herzogtums Preußen. Berlin, 1971. Teil I, 17.

25 Stamm H.-M. Luthers Stellung zum Ordensleben. S. 64

${ }^{26}$ Hubatsch W. Albrecht von Brandenburg - Ansbach: Deutschordens-Hochmeister und Herzog in Preussen 1490-1568. S. 121. 
local gentry, and the burghers of Koenigsberg ${ }^{27}$. Similar attitudes among the different social classes were partly evidenced by the Order's Treasurer, Cleopas Wroer, writing in his letter to Albrecht of December 18, 1524 that his subjects wanted him to pass his power on by inheritance ${ }^{28}$. Under the circumstances, the Grand Master's offer for the brotherhood knights to take secular office was bound to be accepted ${ }^{29}$.

At the same time the rumor had it that Wolter von Plettenberg, Landmaster of the Teutonic Order in Livonia followed the example of Albrecht, although the Order continued to exist on the territory of Livonia until 1561. Up until this point, however, the Landmaster had sought to settle the Evangelical Faith issue with regard to the relationships between classes. This was confirmed in the Wenden (Cèsis) contract signed on April 1, 1533. The compact included different classes of the people of Livonia, the Order and Margrave Wilhelm of Brandenburg. One of the main provisions declared that "the divine Holy word according to the biblical Scripture of the Old and New Testaments shall henceforth be preached freely and unhindered, with no one having to suffer for their religion..." ${ }^{30}$ It is important to note that this area had expressed the desire to solve the religious issues earlier than the rest of the Holy Roman Empire. This is partly due to the fact that military order's knights sought the support of different classes, and partly to their personal sympathies towards Protestantism. Under the influence of external factors, primarily the Livonian war, this policy culminated in the second stage of secularization of the Order in the Baltic States. It was concluded in 1561 upon the signing of the so-called Pacta Subjectionis, which transformed the Ordensstaat into a new political territory - the Duchy of Courland and Semigallia, and made it a vassal of the Polish king.

The Landmaster of the Teutonic Order in Livonia Gotthard von Kettler found himself in somewhat similar circumstances to the ones experienced by Albrecht von Brandenburg-Ansbach in his time. The conversion of the Order's possessions in Livonia had followed a similar scenario. Some historical writings of the 18 century gave the act of the first Duke a positive evaluation. According to Betnedikt Heinrich Heyking, the possible author of "Ius eligendi Ducem..."31 treatise, this enabled to maintain control of the "German"

${ }^{27}$ Besch Th. Friedrich von Heydeck, ein Beitrag zur Geschichte der Reformation und Säkularisation Preussens. Königsberg, 1897. S. 479.

28 “...Die Undirthanen [...] einen Erbherren begeren und Ew. Fürstl. Gnade ouch davor erkennen und annhemen sollen...” (Nicolovius A. Die bischöfliche Würde in Preußens evangelischer Kirche. Ein Beitrag zur Geschichte des evangelischen Kirchenrechts. Königsberg, 1834. S. 97).

29 Boockmann H. Der Deutsche Orden. München, 1989. S.219.

30 “...Das hillige, gottliche Wordt lant denn biblischen Schriften alten vnnd neue Testament soll frei und ungehindert verkuningt warden, nimand in sinen gelouen beentrechtigt warden. Jde obrigkeit soll darüber wuchen, dat prediger erwählt warden, sie das godeswort lauter und klar verkündigen und sich alles lesterns undt schlechtens erhalten; thun sie das letztere dennoch, so sollen sie, wenn sie nach drejmaliger rmahnung nietdavon abstellen, gebürlick gestarft edder ganz abgesetzt warden. Die stennde verplichten sich, einander treu mit rath undt Tath beizustehen. Wenn von drei Parten (der Coadjutor met seyn stennden, der Meister met seyn stennden und die Stadt Riga) zwei uneins werdden, so soll der dritte Part die beiden anderenn freundlich und gütlich zu versönen suchen...jder stand soll bei seyner Regierung, herrlichkeit, freier wahl unddt Postulation, Privilegien undt gerechtigkeit erhalten warden..." (Monumenta Livoniae Antiquae, 1844, N 159, p. 382).

${ }^{31}$ Heyking B. H. Ius eligendi Ducem, statibus Curlandiae et Semigaliae exprincipiis juris naturalis vindicatim. Warsowiae, 1736. P. 4. The authorship of the treatise is not exactly established. One could find the opinion that the author of this treatise is Christian von Wolff. See URL: http://www.europeana.eu/portal/record/9200386/BibliographicResource_3000044976421.html (accessed 12.09.2015). In this case we support Karol Estreicher's point of view. See: Estreicher K. Bibliografia polska. Kraków, 1888. Vol.9. P. 158. 
lands, due to the lack of assistance from the Empire during the Livonian war $^{32}$. Since the Duchy of Courland and Semigallia had moved into the political orbit of the Polish crown, saving "German" lands means preserving their cultural, including religious, component. The secular Duchy was formed from the lands of the Order against the background of the Livonian war, which had served as the catalyst for the process.

In much the same manner the Grand Master of 1525, Gotthard von Kettler, carried out the process of secularization with the direct participation of the Polish crown, whose vassal he also had to become. It is possible that the Livonian Landmaster chose to secularize the Order's property because he already had the Prussian experience at his disposal, which accounted for the external similarity of both processes. Besides the similar historical conditions (expiration of the truce with Poland in the first case and the conflict with the Moscow government in the second), we can also identify a similar religious component. We can see Protestantism being adopted in both cases. It is difficult to determine whether the choice in favor of Lutheranism was made solely for political aspirations. Of course, secularization through the rejection of Catholicism inevitably led to the destruction of ideological foundations of the corporation of the spiritual knighthood. The mechanism is clear. At the same time the Grand Master's and Landmaster's personal sympathies towards Protestantism are also hard to ignore. Albrecht von Brandenburg - Ansbach's correspondence with Luther and Melanchthon had already been mentioned, but his personal attitude to the Evangelical Faith was also confirmed by the fact that both he and knights of the former Prussian Teutonic Order contributed to the success of preacher Prenner and cleric Profell in $1526^{33}$.

As for the character of Gotthard von Kettler, we know that while still holding the post of the Commander of Dunaburg, he expressed his desire to open a Protestant school in which the foundations of the new doctrine would be studied. To this end, he sent his envoy to the Riga Commander, Georg von Syberg, to ask him to invite David Zitreous from Rostock to be the founder of elementary or high Protestant school in Pernau ${ }^{34}$. As for the importance of the religious component in the formation of the Duchy of Courland and Semigallia, the Polish king supported Kettler's desire to retain "the accepted religion" (angenomennen Religionen) ${ }^{35}$ during the Vilnius pact in 1559, which in this case was Protestantism. The idea of Polish citizenship was further discussed at the meeting of the Gebietiger of the Order, summoned by Gotthard Kettler on April 5, 1560, in Riga. The Landmeister spoke of the Order's dire situation according to which 'it existed only

32 “...Hic primumpen debat a Supero Ordinis Teutonici Prussia Magistro: sed Plettenbergius Magister Ordinis in Livonia, certapecunlae vim adejus Superioritate se ordinem que suum liberabat. Qui facto Livonia civitas liberae vasit... Cum sui Ordinis Magistro, Gotthardo Kettler, Livonia bello infolici implicata, adversus vim hostiumsese defendere amplius non posset, omnibus porsus auxiliis a Caesare atque Ordinibus Imperii destitura; id tandem consilii Magister Ordinis ac status Livoniae unversi, facta de liberatio tieun animi tercepereuttutelae Regis Poloniae... In hoc subjectionis formam conseciebat Sigismundus Augustus Poloniae Rex, \& hoc pacto Magistro Ordinis, Gotthardo Kettler, cessit Curlandiae \& Semigaliae, in Ductum tanguam feudum haereditarum; Pacta subjectionis conficiebanque Vilnae d. XXVIII. Nov. An. 1561...” (Heyking B. Ius eligendi Ducem, statibus Curlandiae et Semigaliae. P. 5).

33 Dixon S. The Reformation and rural society // The parishes of Brandenburg-Ansbach-Kulmbach 1528-1603. Cambrige, 1995. P. 18.

${ }^{34}$ Russow B. Chronica der Provintz Lijfflandt // Scriptores rerum Livonicarum. Riga; Leipzig, 1848. Bd. II. S. 11.

35 “...Religionem apud nos usu receptam..." (Kallmeyer Th. Die Begründung der evangelisch-lutherischen Kirche in Kurland durch Herzog Gotthard: ein kirchengeschichtlicher Versuch. Riga, 1851. S. 42). 
in name. The Landmeister and the Gebietigers arrived at the conclusion that they should again attempt to turn the tide of the war by resorting to foreign aid, by which under the circumstances they probably meant Poland.

If the above-mentioned efforts resulted in failure, a no less, if not a more important, option for further development was offered. The idea was that it would be possible to put an end to the crisis by the Landmeister adopting the title of the secular lord and entering a "Christian marriage" (christliche Verheiratung) ${ }^{36}$.

Firstly, it is important to note that the "Christian marriage" had probably meant a union with a Protestant family member, which follows from the formula analogous to the "christliche Ehe" 37 . The choice of Anna of Mecklenburg, professing Protestantism, is the proof. Secondly, discussing the possibility of marriage was in itself an important fact. This is, of course, a natural thing for a secular sovereign to do. The way the Gebieters perceived the questionof marriage as a way out of the crisis, however, might tell us a lot about understanding the necessity to change the diplomatic strategy. While in the Middle Ages and Early Modernity, dynastic marriages often served as a way to create or strengthen unions, the Teutonic Order ruled out this opportunity because of the vow of celibacy that the spiritual knights had to take.

The aforementioned Gebieter meeting enables us to discuss the relationship between Reformation and Secularization in Livonia. There was the idea that if it was not possible to bring the war to a turning point, then the result "would be to expect the sudden fall and separation of Christian classes and the fall of the pure and blessed word of God to irreversible death, not only in Livonia, as the stronghold of Christianity, but in all the neighboring lands..." 38 . Picturing Livonia as the "stronghold of Christianity" is quite understandable rhetoric for the military order. In the present context, however, the meaning of this characteristic may change, as a new kind of thought was voiced along with the possibility of marriage during the discussion of ways out of crisis. The text contains the following lines: "...for the people and the whole Order, while lands are lost through dubious illusions and consolations, it would be nice, wholesome and in keeping with the Christian tradition, to achieve the peace of mind through Christian change..." ${ }^{39}$. The discussion of "Christian change" not only reveals the frame of mind inside the Order but also gives the idea of what was going among the burghers and knights. The "Christian change" must have meant the adoption of Protestantism. Both Kettler's tendency to incline to the Evangelical faith, and the already mentioned view on the possibility of marriage support this view.

36 “...Im Fall durch eine christliche Verheiratung ergötzliche Mittel zum Heil den armen bedrückten Landen zu fiinden sich auf alle Ordenslande zu Liefland al seine natürlicher Erbfürst bei dem zuträglichen Potentaten, zu verändern und zu verheiraten" (Ibid.).

${ }^{37}$ Kamerau W. Die Reformation und die Ehe. Ein Beitrag zur Kulturgeschichte des sechzenten Jahrhunderts. Halle, 1892. S. 52; Dietrich H.Das protestantische Eherecht in Deutschland bis zur Mitte des 17 Jahrhunderts. München, 1970. S.21.

38 “...Plötzlich Untergang und Zetrennung der christlichen Gemeine und das reinen seeligmachenden Wortes Gottes nicht allein über Liefland, als eine Vormauer der Christenheit, sondern in die Längde und endlichen überallebenachbarten Christen Lande zu unwiederbringlichen Verderbzuvermuthen..." (Kallmeyer Th. Die Begründung der evangelisch-lutherischen Kirche in Kurland durch Herzog Gotthard: ein kirchengeschichtlicher Versuch. S. 42, 44).

39 “...Eschristlicher und zuträglicher, auch den Personen und ganzen Orden rühmlicher ware, Hülfe und Errettung durch ChristlicheVeränderung zu erholen und zu Erlangen, als durch zweifelhafftigen Wahn und ungewissen Trost die Lande zu verlieren und derselben vertrieben zu warden..." (Ibid. S. 45). 
An important role in preserving Protestantism in the process of formation of the Duchy of Courland and Semigallia and the boundaries belonged to a Polish magnate Nikolas Radziwill the Black (Mikołaj 'Czarny' Radziwiłł), who had held the position of Chancellor of the Great Duchy of Lithuania at the time. He personally negotiated with Kettler during the Vilnius talks. We can't but agree with K. Schmidt, who noted that this fact could affect the appearance of the "Sigismund Augustus Privileges" fragment associated with supporting religious freedom in the Augsburg interpretation (confessio Augustana) ${ }^{40}$. Paragraph 4 guaranteed Livonia extensive privileges in the sphere of management and law. Comparing the privileges of Sigismund August (Privilegium Sigismundi Augusti) ${ }^{41}$. with the Pacta Subjectionis ${ }^{42}$, it is impossible to overlook the similarity of opinion on the question of religion. It is postulated in Chapter 7 of the Privileges that the Duke guarantees his subjects the freedom of religious rituals ${ }^{43}$. Gotthard von Kettler later confirmed this position in his Privilege (Privilegium Gotthardinum) in $1570^{44}$.

The formation of the Duchies of Prussia, Courland and Semigallia was happening) along with the secularization of the possessions of the Teutonic Order).The Baltic region, because of its established trade contacts with the Northern German cities, which had survived after the political transformation of the territory, also kept cultural links with the lands belonging to the Holy Roman Empire. One of the ways for implementing this transformation was the activity of the Protestant preachers who went to the Baltic States. Protestantism, which served to delineate the confessional borders between Poland and The Great Duchy of Lithuania and Protestant Duchies had not only become a religious, but a cultural marker of the Baltic lands.

The fact was that the conditions in Prussia and Livonia were somewhat different, which may have determined the different ways that these two Order states had developed. There were two major contributing factors. One of them concerned the principle of recruiting new members for the military order according to their region. Unlike the Prussian branch whose members, as a rule, came from the Rhine lands, the Livonian branch was mainly comprised of the natives of Westphalia lands ${ }^{45}$. This was the region of the Holy Roman Empire where the Reformation processes started later than in Franconia and Brandenburg. In this regard, given the ties that the Order members had kept to their families in the Empire, it is extremely likely that their personal attitude towards Protestantism was influenced not only by Livonian, but also by Westphalian processes. This contributed to the later popularity of Evangelical doctrine among the Livonian brethren compared to the Prussian members of the Order.

The second factor had to do with the overall active counter-Reformation position of the institute of bishops, which was the Order's traditional Livonian opponent. Thus, supporting Protestantism became the element of opposition to the claims of the episcopate, at least in the 20-30s. The Livonian model differed significantly from the Prussian one, where the bishops were directly included in the spiritual knighthood corporation. The authority of the church structures was much stronger in Livonia, which was, among oth-

40 Schmidt Ch. Auf Felsen gesät die Reformation in Polen und Livland. Göttinegen, 2000. S. 206.

${ }^{41}$ Codex Diplomaticus Regni Poloniae. Et Magni Ducatus Lituaniae. Vilnae, 1759. T. V. P. 243-248.

${ }^{42}$ Ibid. P. 240.

43 Ibid. P. 245 .

${ }^{44}$ Schmidt Ch. Auf Felsen gesät die Reformation in Polen und Livland. S. 207.

${ }^{45}$ Neitmann S. Von der Grafschaft Mark nach Livland. Ritterbrüder aus Westfalen in livländischen Deutschen Orden. Köln, 1993. 
er factors, due to the Livonian episcopate being closely integrated into the Holy Roman Empire's dynastic ties system. The largest Northern German noble families took part in the competition to win over the local parishes, and they were not always interested in the secularization of their relatives' property.

The specific character of the Livonian Reformation processes becomes evident when compared to those in the Holy Roman Empire. On the territory subordinate to to the spiritual knighthood corporation, attempts at resolving conflicts in the relationships between supporters of Catholicism and Protestantism had begun to appear before the conclusion of Augsburg peace in 1555, which was largely due to the Order's necessity to maintain control over its possessions. In addition, the need for a new doctrine was felt here more acutely, as the Corporation was dependent on it not only as suzerain, but also for its continued existence as a spiritual knighthood organization.

It is evident that discussing the issues of Reformation and Confessionalization on the territory of the Order's estates in Prussia, and especially in Livonia, we deal with a kind of political Reformation not covered by the typology given at the beginning of the article. Despite belonging to Imperial princes, Albrecht von Brandenburg-Ansbach and Landmeister Gotthard von Kettler were first of all leaders of the military order . In this regard, the events in Livonia, can hardly be classified as "Fürstenreformation" in its classic sense. Yet, is it possible to classify the Ordensstaat events as "Städtereformation"? On the one hand, the position of the cities played an important role in the spread of Protestantism, on the other hand, one cannot ignore the suzerain's attitude to faith, which was undoubtedly the position held by the Teutonic Order. Of course, the influence of the burghers was significant. Neither the Grand Master in Prussia nor landmaster in Livonia could afford to ignore the Protestantism spreading in the cities. However, this class did not initiate secularization. That is why, we have to be very cautious while speaking about this type of Reformation. We are of the opinion, however, that we can talk about a specific character of these processes, or, given the special characteristics of the Order, of the 'corporate' type of Reformation. Besides, these examples indicate the beginning of the age of Confessionalization starting in the mid 20-ies of the XVI century, i.e. somewhat earlier than it was assumed in historiography.

\section{References}

Arnold U. Hochmeister Albrecht von Brandenburg - Ansbach und Landmeister Gotthard Kettler. The Military orders and the Reformation. Choices, state building and the weight of tradition. Utrecht, Hilversum Verloren Publ., 2006, Ss. 11-31.

Besch Th. Friedrich von Heydeck, ein Beitrag zur Geschichte der Reformation und Säkularisation Preussens. Altpreußische Monatsschrift, 1897, no. 34, Ss. 473-535.

Boockmann H. Der Deutsche Orden. München, Verlag C. H. Beck, 1989, 319 S.

Brady Th. Turning Swiss. Cities and Empire 1450-1550. Cambridge, Cambridge University Press, 1985, 288 p.

Dietrich H.Das protestantische Eherecht in Deutschland bis zur Mitte des 17 Jahrhunderts. München, Claudius Verlag, 1970, 297 S.

Dixon S.C. The Reformation and rural society: the parishes of Brandenburg-Ansbach-Kulmbach 1528-1603. Cambrige, Cambridge University Press, 1995, 237 p.

Dolezel S., Dolezel H. Die Staatsverträge des Herzogtums Preußen. Berlin; Köln, Grote Publ., 1971, Part I, $228 \mathrm{p}$.

Estreicher K. Bibliografia polska. Kraków, Drukarnia Uniwersytetu Jagiellońskiego, 1888, vol. 9, 979 p. 
Foschepoth J. Reformation und Bauernkrieg im Geschichtsbild der DDR. Zur Methodologie einer Gewandelten Geschichtsverständnisses. Berlin, Dunckler \& Humblot Publ., 1976, 173 S.

Greyerz K. von. Stadt und Reformation: Stand und Aufgaben der Forschung. Archiv für Reformationsgeschichte, 1985, no. 76, Ss. 6-63.

Hirscheydt Magnus. Die Säkularisationen der geistlichen Staaten Livlands 1558-1561. Typologie und Verglech. Latvijas Zinātṇu akadēmijas vēstis. A dặa, Sociālās un humanitārās zinātnes, 2013, no. 67, Ss. $90-107$.

Hubatsch W. Albrecht von Brandenburg-Ansbach: Deutschordens-Hochmeister und Herzog in Preussen 1490-1568. Heidelberg, Quelle \& Meyer Publ., 1960, 354 S.

Jankiewicz A. Inflanty i Księstwo Kurlandii i Semigalii - inflanckie "rusy" trochę inaczej. Kilka uwag o zapomnianej Unii Wileńskiej 1561 roku. Miscellanea Historico-Archivistica, 2013, no. 20, pp.19-43.

Klueting H. Das konfessionelle Zeitalter 1525-1648. Stuttgart, Verlag Primus, 1989, 480 S.

Kreem J. Der Deutsche Orden und die Reformation in Livland. The Military orders and the Reformation. Choices, state building and the weight of tradition. Utrecht, Hilversum Verloren Publ., 2006, pp. 43-59.

Kuhles J. Die Reformation in Livland - religiöse, politische und ökonomische Wirkungen. Hamburg, Kovac Dr. Verlag, 2007, 295 S.

Łowmiański H. Rol' rytsarskikh ordenov v Pribaltike XIII-XIV vv. Moskow, Nauka Publ., 1974, pp. 67-80.

Martin Luther's Briefe, Sendschreiben und Bedenken. Hrsg. von Leberecht der W. M. Wette. Berlin, G. Reimer Publ., 1826, Bd. 2, 680 S.

Moeller B. Reichsstadt und Reformation. Berlin, Mohr Siebeck Verlag, 1987, 244 S.

Monumenta Livoniae Antiquae. Riga; Leipzig, Eduard Frantzen's Verlag - Comptoir, 1844, Bd. 4, 700 S.

Mühlen H. z. von. Livland von der Christianisierung bis zum Ende seiner Selbständlichkeit (etwa 11801561). Baltischer Länder. Hrsg. von G. von Pistohlkors. Berlin, Siedler Verlag, 1994, Ss. 26-172.

Neitmann S. Von der Grafschaft Mark nach Livland. Ritterbrüder aus Westfalen in livländischen Deutschen Orden. Köln, Böhlau Publ., 1993, 673 S.

Oberländer E. Księstwo Kurlandii jako rzeczpospolita szlachecka 1561-1795. Czasopismo Prawno - Historiczne, 1993, t. 42, no. 1-2, pp. 269-281.

Politik und Religion: Eigenlogik oder Verzahnung? Europa im 16. Jahrhundert. Hrsg. von R. von Friedeburg, L. Schorn-Schütte. München, Oldenbourg Verlag, 2007, 165 S.

Preussen und Livland im Zeichen der Reformation. Hrsg. von A. Mentzel-Reuters, K. Neitmann. Osnabrück, Fibre Verlag, 2014, 368 S.

Rabe H. Reich und Glaubensspalting. Deutschland 1500-1600. München, Verlag C. H. Beck, 1989, 517 S.

Reinhard W. Zwang zur Konfessionalisierung? Prolegomena zu einer Theorie des konfessionellen Zeitalters. Zeitschrift für historische Forschung, 1983, Bd. 10, Ss. 257-277.

Reinhard W. Probleme deutsche Geschichte 1495-1806. Reichsreform und Reformation 1495-1555. Stuttgart, Oldenbourg Verlag, 2001, Ss. 3-107.

Rudersdorf M. Die deutsche Reformation - nur ein "urban event"? Europa in der Frühen Neuzeit. Köln; Weimar; Wien, Böhlau Publ., 2002, Ss. 116-120.

Schilling H. Aufbruch und Kriese: Deutschland 1517-1648. Berlin, Siedler Taschenbuch, 1998, 508 S.

Schilling H. Reformation - Umbruch oder Gipfelpunkt eines Temps des Reformes. Die frühe Reformation in Deutschland als Umbruch: Wissenschaftliches Symposion des Vereins für Reformationsgeschichte 1996. Gütersloh, Gütersloher Verlagshaus, 1998, Ss. 13-34.

Schilling H. Konfessionalisierung und Staatsinteressen: internationale Beziehungen 1559-1660. Paderborn, Ferdinand Schöningh Verlag, 2007, 687 S.

Schmidt C. Auf Felsen gesät die Reformation in Polen und Livland. Göttinegen, Vandenhoeck \& Ruprecht Publ., 2000, 341 S.

Schmidt H. R. Konfessionalisierung im 16. Jahrhundert. München, Oldenbourg, 1992, 153 S.

Schulze W. Gerchard Osterreichs Begriff "Sozialdisziplierung in der Frühen Neuzeit". Zeitschrift für Historische Forschungen, 1987, Bd. 14, Ss. 265-302.

Skalweit S. Gestalten und Probleme der frühen Neuzeit. Berlin, Duncker \& Humblot Publ., 1987, 229 S.

Stamm H.-M. Luthers Stellung zum Ordensleben. Der Durchbruch der reformatorischen Erkenntnis bei Luther. Neuere Untersuchungen. Mainz, Verlag Philipp von Zabern in Wissenschaftliche Buchgesellschaft, 1980, Ss. 38-57.

Weber D. Posledniy magistr v Livonii. Vestnik of Novosibirsk State University, 2014, vol. 1, pp. 19-24. (In Russian) 
Wohlfeil R. Reformation als frühbürgerliche Reformation? Die deutsche Reformation in der Historiographie der DDR. Geschichtswissenschaft in der DDR. Vor- und Frühgeschichte bis Neueste Geschichte. Berlin, Duncker \& Humblot Publ., 1990, Ss. 174-214.

Wolgast E. Formen landesfürstlicher Reformation in Deutschland. Kursachen-Württenberg-Kurpfalz. Die dänische Reformation vor ihrem internationalen Hintergrund. Göttingen, Vandenhoeck \& Ruprecht Publ., 1990, Ss. 57-90.

Ziegler W. Territorium und Reformation. Historisches Jahrbuch, 1990, Bd. 110, Ss. 52-75.

Received: 05.06.2017

Accepted: 28.12.2017 